\title{
Oxidative enzyme activities of the vastus lateralis muscle and the functional status in patients with COPD
}

François Maltais, Pierre LeBlanc, François Whittom, Clermont Simard, Karine Marquis, Marthe Bélanger, Marie-Josée Breton, Jean Jobin

\begin{abstract}
Background-Enzymatic and histochemical abnormalities of the peripheral muscle may play a role in exercise intolerance in patients with chronic obstructive pulmonary disease (COPD). A study was undertaken to measure the mitochondrial enzyme activity of the vastus lateralis muscle in patients with COPD and to evaluate the relationship between enzyme activities and functional status.
\end{abstract}

Methods-Fifty seven patients with COPD of mean (SD) age 66 (7) years with forced expiratory volume in one second $\left(F_{1} V_{1}\right) 39(15) \%$ predicted and peak oxygen uptake $\left(\dot{\mathrm{V}}_{2}\right)$ of 14 (4) $\mathrm{ml} / \mathrm{min} / \mathrm{kg}$ and 15 normal subjects of similar age were included in the study. Each subject performed a stepwise exercise test up to maximal capacity during which fivebreath averages of $\dot{\mathrm{V}}_{2}$ were measured. Muscle specimens were obtained by percutaneous needle biopsy of the vastus lateralis muscle and the activity of two mitochondrial enzymes (citrate synthase (CS) and 3-hydroxyacyl CoA dehydrogenase (HADH)) was measured. The functional status of the patients was classified according to peak $\dot{\mathrm{V}}_{2}$.

Results-CS and HADH activities were markedly reduced in patients with COPD compared with normal subjects $(22.3$ (2.7) versus $29.5(7.3) \mu \mathrm{mol} / \mathrm{min} / \mathrm{g}$ muscle $(\mathrm{p}<0.0001)$ and $5.1 \quad(2.0)$ versus 6.7 (1.9) $\mu \mathrm{mol} / \mathrm{min} / \mathrm{g}$ muscle $(p<0.005)$, respectively). The activity of CS decreased progressively with the deterioration in the functional status while that of HADH was not related to functional status. Using a stepwise regression analysis, percentage predicted functional residual capacity (FRC), the activity of CS, oxygen desaturation during exercise, age, and inspiratory capacity (\% pred) were found to be significant determinants of peak $\dot{\mathrm{V}} \mathrm{O}_{2}$. The regression model explained $59 \%$ of the variance in peak $\dot{\mathrm{V}}_{2}(\mathbf{p}<0.0001)$.

Conclusions-The oxidative capacity of the vastus lateralis muscle is reduced in patients with moderate to severe COPD compared with normal subjects of similar age. In these individuals the activity of CS correlated significantly with peak exercise capacity and independently of lung function impairment.

(Thorax 2000;55:848-853)
Keywords: chronic obstructive pulmonary disease; exercise; oxidative enzymes

The function of the skeletal peripheral muscle and its contribution to exercise intolerance in patients with chronic obstructive pulmonary disease (COPD) is currently being investigated. Because of the invasive nature of the muscle biopsy technique, studies of the oxidative capacity of the skeletal muscle in patients with COPD have only included a small number of patients. This may explain the discrepant results reported on the distribution of fibre types and the oxidative capacity of the vastus lateralis muscle in this population. ${ }^{1-6}$ Some studies have found a reduction in the proportion of type I fibres ${ }^{2-4}$ and in the mitochondrial enzyme activities ${ }^{67}$ in patients with COPD compared with healthy subjects, while others have reported no difference between the two groups in the proportion of type I fibres. ${ }^{15}$

While it has been convincingly shown that peripheral muscle weakness contributes to exercise intolerance in patients with COPD, ${ }^{8}$ the possible impact of the morphological and enzymatic characteristics of skeletal muscle on exercise tolerance is less obvious. ${ }^{69}$ Although the capacity of the oxidative metabolism of the skeletal muscle may not be exhausted at peak exercise,${ }^{10}$ there is substantial evidence to support the notion that poor muscle oxidative capacity may influence exercise tolerance in patients with COPD. Muscle homeostasis is better maintained during exercise when muscle oxidative capacity is high, with less lactate and $\mathrm{CO}_{2}$ production for a given exercise level. ${ }^{11}$ These metabolic consequences, by reducing the ventilatory requirements, may be particularly relevant in patients with COPD and limited ventilatory capacity. ${ }^{12} 13$

It is, however, difficult to draw a firm conclusion from the literature on the potential role of the morphological and enzymatic characteristics of skeletal muscle on exercise tolerance in COPD. A strong linear relationship was observed between the activity of two mitochondrial enzymes and peak oxygen uptake $\dot{\mathrm{V}}_{2}$, while a subsequent study failed to show an independent effect of fibre type on exercise tolerance in patients with COPD. ${ }^{9}$ These apparently discrepant results may be explained by different adaptive responses of the enzyme activity and fibre type profile. For instance, exercise training induces a marked increase in oxidative enzyme activity with little or no effect on the fibre type profile, ${ }^{14}$ indicat- 
Table 1 Characteristics of study subjects, pulmonary function tests, and peak exercise data

\begin{tabular}{|c|c|c|}
\hline & $\begin{array}{l}\text { Normal } \\
\text { subjects }(n=15)\end{array}$ & $\begin{array}{l}C O P D \\
(n=57)\end{array}$ \\
\hline Age (years) & $62(5)$ & $66(7)$ \\
\hline Body mass index $\left(\mathrm{kg} / \mathrm{m}^{2}\right)$ & $26(4)$ & $25(5)$ \\
\hline $\mathrm{FEV}_{1}(\mathrm{l})$ & $2.88(0.28)^{\mathrm{a}}$ & $1.04(0.41)^{\mathrm{b}}$ \\
\hline $\mathrm{FEV}_{1}$ (\% pred) & $106(9)^{\mathrm{a}}$ & $39(15)^{\mathrm{b}}$ \\
\hline FVC (1) & $3.68(0.40)^{\mathrm{a}}$ & $2.57(0.70)^{\mathrm{b}}$ \\
\hline FVC (\% pred) & $94(8)^{\mathrm{a}}$ & $64(16)^{\mathrm{b}}$ \\
\hline TLC (\% pred) & - & $117(18)$ \\
\hline TLCO (\% pred) & - & $66(24)$ \\
\hline$\dot{\mathrm{V}} \mathrm{O}_{2}(\mathrm{ml} / \mathrm{kg} / \mathrm{min})$ & $29(8)^{\mathrm{a}}$ & $14(4)^{\mathrm{b}}$ \\
\hline Work rate (watt) & $156(39)^{a}$ & $52(28)^{\mathrm{b}}$ \\
\hline$\dot{\mathrm{V}} \mathrm{E}(1 / \mathrm{min})$ & $75(19)^{\mathrm{a}}$ & $36(13)^{\mathrm{b}}$ \\
\hline$\dot{\mathrm{V}} \mathrm{E} / \mathrm{MVV}(\%)$ & $74(18)$ & $90(23)$ \\
\hline Heart rate (beats/min) & $156(10)^{\mathrm{a}}$ & $131(19)^{\mathrm{b}}$ \\
\hline Heart rate (\% max pred) & $92(7)^{\mathrm{a}}$ & $79(11)^{\mathrm{b}}$ \\
\hline \multicolumn{3}{|l|}{ Borg scores } \\
\hline Dyspnoea & $5.0(3.1)$ & $7.3(2.1)$ \\
\hline Leg fatigue & $5.2(3.5)$ & $5.7(3.0)$ \\
\hline \multicolumn{3}{|l|}{$\mathrm{SaO}_{2}$} \\
\hline Rest & $0.98(0.01)^{\mathrm{a}}$ & $0.96(0.04)^{\mathrm{b}}$ \\
\hline Peak exercise & $0.98(0.01)^{\mathrm{a}}$ & $0.90(0.07)^{\mathrm{b}}$ \\
\hline \multicolumn{3}{|l|}{$\mathrm{PaCO}_{2}(\mathrm{kPa})$} \\
\hline Rest & $5.2(0.5)$ & $5.6(0.9)$ \\
\hline Peak exercise & $4.9(0.7)^{\mathrm{a}}$ & $6.4(1.2)^{\mathrm{b}}$ \\
\hline \multicolumn{3}{|l|}{ Lactate $(\mathrm{mmol} / \mathrm{l})$} \\
\hline Rest & $0.75(0.40)$ & $0.98(0.63)$ \\
\hline Peak exercise & $8.06(2.38)^{\mathrm{a}}$ & $3.91(2.02)^{\mathrm{b}}$ \\
\hline
\end{tabular}

$\mathrm{FEV}_{1}=$ forced expiratory volume in one second; FVC = forced vital capacity; TLC $=$ total lung capacity; $\mathrm{TLCO}_{\mathrm{L}}=$ carbon monoxide transfer factor; $\dot{\mathrm{V}}_{2}=$ oxygen output; $\dot{\mathrm{VE}}=$ minute ventilation.

Values are mean (SD). Values followed by different letters are significantly different.

ing that changes in exercise tolerance and fibre type profile may be dissociated. We therefore reasoned that oxidative enzyme activities were more appropriate to evaluate the possible relationship between muscle function and exercise tolerance in patients with COPD than the fibre type profile.

Accordingly, the present study was undertaken to test the hypothesis that the oxidative enzyme activity is reduced in patients with COPD compared with normal subjects and that oxidative enzyme activity is one determinant of exercise tolerance in patients with COPD. To address these issues, muscle biopsy specimens were obtained from a large number of patients with COPD in order to quantify the mitochondrial enzyme activity of the vastus lateralis muscle and to investigate its potential relationship with the functional status. The determinants of peak exercise capacity were also evaluated in these patients.

\section{Methods}

SUBJECTS

Fifty seven consecutive patients with COPD (49 men) evaluated at the exercise physiology laboratory of our hospital and in whom a needle biopsy specimen of the vastus lateralis muscle was performed were included in the study. The diagnosis of COPD was based on previous or current smoking history and pulmonary function tests showing irreversible bronchial obstruction. ${ }^{15-17}$ Patients were clinically stable at the time of the study and none suffered from cardiovascular, neurological, or any other condition that could impair capacity to perform an exercise test. Patients were on the following pharmacological treatments: short acting $\beta_{2}$ agonists ( $\left.\mathrm{n}=57\right)$; long acting $\beta_{2}$ agonists $(n=8)$; ipratropium bromide $(n=29)$; inhaled corticosteroids $(n=40)$; low dose (5$15 \mathrm{mg}$ ) oral prednisone $(\mathrm{n}=6)$. Fifteen healthy non-smokers (13 men) aged 55-70 years were recruited by means of a newspaper advertisement to serve as controls. None of these subjects was involved in a regular exercise programme. Neither COPD patients nor normal subjects had taken part in previous studies in our laboratory on peripheral muscle function. The research protocol was approved by the institutional ethics committee and signed informed consent was obtained in each case.

PROTOCOL

Pulmonary function tests

Standard pulmonary function tests including spirometry, lung volumes, and carbon monoxide transfer factor (TLCO) were performed in patients at baseline according to previously described guidelines ${ }^{18}$ and related to normal values of Knudson, ${ }^{15}$ Goldman and Becklake, ${ }^{16}$ and Cotes, ${ }^{17}$ respectively. Only spirometric tests were performed in normal subjects.

\section{Exercise test}

After the insertion of an arterial cannula in a radial artery, subjects were seated on an electrically braked cycle ergometer (Quinton Corival 400, A-H Robins, Seattle, WA, USA) and connected to the expired gas analysis circuit through a mouthpiece. Five-breath averages of oxygen uptake $\left(\dot{\mathrm{V}}_{2}\right)$ and minute ventilation ( $\dot{\mathrm{V} E}$ ) were measured by an automated system equipped with a pneumotachograph, $\mathrm{O}_{2}$ and $\mathrm{CO}_{2}$ analysers, and a mixing chamber (Quinton Qplex, A-H Robins, Seattle, WA, USA). After 3-5 minutes of rest a progressive symptom limited stepwise exercise test was performed. Each exercise step lasted one minute and increments of 10 and 20 watts were used in COPD and normal subjects, respectively. Dyspnoea and leg fatigue perception were rated on a modified Borg scale at one minute intervals during exercise. Arterial blood was analysed at rest and at maximal exercise to determine blood lactate concentrations and gas tensions. During exercise blood samples were placed on ice and centrifuged at room temperature immediately after termination of the exercise test. Lactate concentrations were measured on plasma with an enzymatic technique (Kit lactate, Boehringer Mannheim, Mannheim, Germany).

\section{Muscle biopsy}

Percutaneous biopsy specimens of the right vastus lateralis muscle were taken at mid thigh level (15 cm above the patella) as described by Bergström. ${ }^{19}$ Briefly, after local anaesthesia with $2 \mathrm{ml}$ lidocaine $2 \%$ (lignocaine) a $1 \mathrm{~cm}$ skin incision was made and three muscle samples were obtained. These were immediately frozen in liquid nitrogen and stored at $-70^{\circ} \mathrm{C}$ until determination of enzymatic activity. On average, $50-100 \mathrm{mg}$ samples of muscle tissue were obtained per biopsy while approximately $30 \mathrm{mg}$ were necessary for the determination of muscle enzyme activities. 

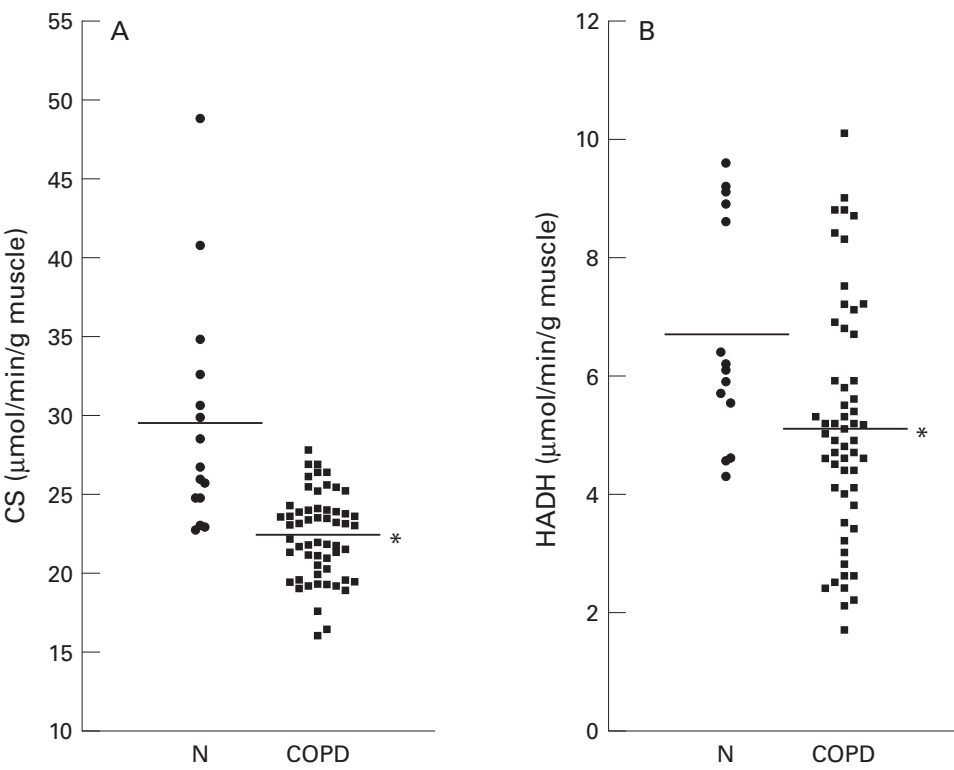

Figure 1 Individual values for the activity of $(A)$ citrate synthase $(C S)$ and $(B)$ 3-hydroxyacyl CoA dehydrogenase (HADH) in normal subjects $(N)$ and patients with chronic obstructive pulmonary disease (COPD). The horizontal lines represent group mean values. The activity of CS and $H A D H$ was significantly decreased in patients with COPD compared with normal subjects ( $p<0.0001$ and $p<0.005$, respectively).

Table 2 Characteristics of study subjects in relation to the functional status

\begin{tabular}{|c|c|c|c|c|}
\hline & Class D $(n=10)$ & Class $C(n=28)$ & Class $B(n=15)$ & Class $A(n=4)$ \\
\hline Age (years) & $65(8)^{\mathrm{ab}}$ & $69(5)^{\mathrm{a}}$ & $62(8)^{b}$ & $56(9)^{b}$ \\
\hline $\operatorname{Sex}(M / F)$ & $7 / 3$ & $24 / 4$ & $14 / 1$ & $4 / 0$ \\
\hline $\mathrm{BMI}\left(\mathrm{kg} / \mathrm{m}^{2}\right)$ & $28.0(7.7)$ & $23.5(3.9)$ & $25.8(4.7)$ & $22.2(2.8)$ \\
\hline $\mathrm{FEV}_{1}(\mathrm{l})$ & $0.68(0.15)^{\mathrm{a}}$ & $1.02(0.36)^{\mathrm{b}}$ & $1.20(0.30)^{\mathrm{b}}$ & $1.56(0.76)^{\mathrm{b}}$ \\
\hline $\mathrm{FEV}_{1}(\%$ pred $)$ & $29(9)^{\mathrm{a}}$ & $39(16)^{\mathrm{ab}}$ & $43(14)^{\mathrm{b}}$ & $48(17)^{\mathrm{ab}}$ \\
\hline FVC (1) & $1.72\left(0.42^{\mathrm{a} a}\right.$ & $2.68(0.62)^{\mathrm{b}}$ & $2.81(0.62)^{\mathrm{b}}$ & $3.04(0.49)^{\mathrm{b}}$ \\
\hline FVC (\% pred) & $48(11)^{\mathrm{a}}$ & $68(15)^{\mathrm{b}}$ & $68(14)^{\mathrm{b}}$ & $69(13)^{\mathrm{b}}$ \\
\hline $\mathrm{FEV}_{1} / \mathrm{FVC}(\%)$ & $41(11)$ & $38(10)$ & $43(8)$ & $52(25)$ \\
\hline FRC (\% pred) & $172(30)^{\mathrm{a}}$ & $150(35)^{\mathrm{ab}}$ & $141(16)^{\mathrm{ab}}$ & $122(28)^{\mathrm{b}}$ \\
\hline IC (\% pred) & $55(16)^{\mathrm{a}}$ & $78(17)^{\mathrm{b}}$ & $73(13)^{\mathrm{ab}}$ & $89(8)^{\mathrm{b}}$ \\
\hline TLC (\% pred) & $123(16)$ & $119(22)$ & $113(11)$ & $109(20)$ \\
\hline TLCO (\% pred) & $65(35)$ & $59(17)$ & $70(26)$ & $90(31)$ \\
\hline $\mathrm{PO}_{2}(\mathrm{kPa})^{2}$ & $9.6(2.3)$ & $10.2(1.6)$ & $11.2(1.5)$ & $11.7(0.5)$ \\
\hline $\mathrm{SaO}_{2}(\%)$ & $93(8)$ & $96(2)$ & $97(1)$ & $98(1)$ \\
\hline $\mathrm{pH}$ & $7.38(0.05)^{\mathrm{a}}$ & $7.42(0.03)^{\mathrm{b}}$ & $7.42(0.03)^{\mathrm{ab}}$ & $7.44(0.01\}^{\mathrm{b}}$ \\
\hline $\mathrm{PCO}_{2}(\mathrm{kPa})$ & $6.5(1.1)^{\mathrm{a}}$ & $5.5(0.8)^{\mathrm{b}}$ & $5.4(0.9)^{\mathrm{b}}$ & $4.9(0.3)^{\mathrm{b}}$ \\
\hline Lactate $(\mathrm{mmol} / \mathrm{l})$ & $1.06(0.70)$ & $1.02(0.70)$ & $0.80(0.41)$ & $0.95(0.22)$ \\
\hline
\end{tabular}

Values are mean (SD). Values followed by different superscript letters are significantly different. $\mathrm{BMI}=$ body mass index $\mathrm{FEV}_{1}=$ forced expiratory volume in one second $\mathrm{FVC}=$ forced vital capacity; FRC = functional residual capacity; IC $=$ inspiratory capacity; TLC $=$ total lung capacity; $\mathrm{TLCO}=$ carbon monoxide transfer factor; $\mathrm{PO}_{2}, \mathrm{PCO}_{2}=$ carbon monoxide and oxygen gas tensions.

DATA ANALYSIS

Determination of muscle enzyme activity

Muscle biopsy specimens were coded and analysed without knowledge of the clinical data. Enzyme activities were measured at $25^{\circ} \mathrm{C}$ and expressed in $\mu \mathrm{mol} / \mathrm{min} / \mathrm{g}$ muscle wet weight. The activities of citrate synthase (CS, EC 4.1.3.7) and of 3-hydroxyacyl CoA dehydrogenase (HADH, EC 1.1.1.35) were measured using a spectrophotometric technique as previously described. ${ }^{20}{ }^{21}$ The reaction media used to measure enzymatic activities were tris- $\mathrm{HCl}$ $15 \mathrm{mM}$ (pH 8.0) containing DTNB $0.016 \mathrm{mM}$, acetyl-CoA $0.1 \mathrm{M}$, and sodium oxaloacetate $0.038 \mathrm{mM}$ for $\mathrm{CS}$ and triethanolamine $100 \mathrm{mM}$ (pH 7.0) containing EDTA $5 \mathrm{mM}$, NADH $0.17 \mathrm{mM}$, KCN $1 \mathrm{mM}$, and acetyl-CoA $0.1 \mathrm{mM}$ for HADH. Each assay was done in duplicate and the average of the two values is reported.
Functional status classification

In patients with COPD the functional status was graded according to peak $\dot{\mathrm{V}}_{2}$ using the approach previously used in chronic heart failure by Weber et $a l^{2}$ where $>20 \mathrm{ml} / \mathrm{kg} / \mathrm{min}=$ mild to no impairment (class $\mathrm{A}, \mathrm{n}=4$ ), $>16$ and $\leqslant 20 \mathrm{ml} / \mathrm{kg} / \mathrm{min}=$ mild to moderate impairment (class $\mathrm{B}, \mathrm{n}=15$ ), $>10$ and $\leqslant 16 \mathrm{ml} / \mathrm{kg} / \mathrm{min}=$ moderate to severe impairment (class $\mathrm{C}, \mathrm{n}=28$ ), and $>6$ and $\leqslant 10 \mathrm{ml} / \mathrm{kg} /$ $\min =$ severe impairment $($ class $\mathrm{D}, \mathrm{n}=10)$.

\section{Statistical analysis}

Values are reported as mean (SD). The maximal voluntary ventilation (MVV) was estimated by multiplying the forced expiratory volume in one second $\left(\mathrm{FEV}_{1}\right)$ by $35 .{ }^{23}$ Comparisons between groups were done using ANOVA and Tukey's comparison test. When normality assumption was not met, values were transformed by rank. A stepwise multiple regression analysis was performed in patients with COPD using peak $\dot{\mathrm{V}}_{2}$ as the dependent variable and pulmonary function tests $\left(\mathrm{FEV}_{1}\right.$, forced vital capacity (FVC), functional residual capacity (FRC), total lung capacity (TLC), inspiratory capacity (IC), and TLCO \% predicted), the activity of CS and $\mathrm{HADH}$, and oxygen desaturation during exercise (resting $\mathrm{SaO}_{2}$ - peak exercise $\mathrm{SaO}_{2}$ ) as independent variables. A value of $p<0.05$ was considered statistically significant.

\section{Results}

Anthropometric characteristics, pulmonary function, peak exercise data, and blood gas tensions for normal subjects and patients with COPD are shown in table 1. Group mean values for age and body mass index were comparable for each group. On average, patients had moderate to severe airflow obstruction and hyperinflation. As expected, exercise tolerance was markedly reduced in patients compared with normal subjects. In patients, exercise was accompanied by a rapid increase in symptom scores, absent or reduced ventilatory reserve, $\mathrm{O}_{2}$ desaturation, and $\mathrm{CO}_{2}$ retention. The pharmacological treatment profile was similar for the four groups.

Individual values for the activity of CS and $\mathrm{HADH}$ are shown in fig 1 . CS and $\mathrm{HADH}$ were significantly reduced in patients with COPD compared with normal subjects $(22.3$ (2.7) versus $29.5(7.3) \mu \mathrm{mol} / \mathrm{min} / \mathrm{g}$ muscle $\begin{array}{lllll}(\mathrm{p}<0.0001) & \text { and } & 5.1 & (2.0) & \text { versus }\end{array} 6.7$ (1.9) $\mu \mathrm{mol} / \mathrm{min} / \mathrm{g}$ muscle $(\mathrm{p}<0.005)$, respectively).

Anthropometric characteristics, pulmonary function, peak exercise data, and blood gas tensions for each functional class of patients are shown in tables 2 and 3. The deterioration in functional status from class $\mathrm{A}$ to $\mathrm{D}$ was accompanied by a progressive reduction in $\mathrm{FEV}_{1}$, an increase in FRC with a concomitant decrease in IC, and by the development of resting hypercapnia. The increase in symptom scores, $\mathrm{O}_{2}$ desaturation, and $\mathrm{CO}_{2}$ retention occurred at a gradually lower exercise level with the deterioration in functional status. 
Table 3 Peak exercise data in relation to the functional status

\begin{tabular}{|c|c|c|c|c|}
\hline & Class D $(n=10)$ & Class $C(n=28)$ & Class $B(n=15)$ & Class $A(n=4)$ \\
\hline$\dot{\mathrm{V}} \mathrm{O}_{2}(1 / \mathrm{min})$ & $0.62(0.16)^{\mathrm{a}}$ & $0.89(0.22)^{\mathrm{a}}$ & $1.25(0.2)^{\mathrm{b}}$ & $1.54(0.17)^{\mathrm{b}}$ \\
\hline$\dot{\mathrm{V}}_{2}(\mathrm{ml} / \mathrm{min} / \mathrm{kg})$ & $8.7(1.6)^{\mathrm{a}}$ & $13.2(1.6)^{\mathrm{b}}$ & $17.4(1.1)^{\mathrm{c}}$ & $23.9(2.0)^{\mathrm{d}}$ \\
\hline Work rate (watts) & $21(8)^{a}$ & $45(16)^{\mathrm{b}}$ & $72(19)^{c}$ & $108(19)^{c}$ \\
\hline $\begin{array}{l}\text { Heart rate } \\
\quad \text { (beats/min) }\end{array}$ & $122(16)^{\mathrm{a}}$ & $127(19)^{\mathrm{a}}$ & $141(11)^{\mathrm{ab}}$ & $156(18)^{\mathrm{b}}$ \\
\hline Heart rate (\% max $)$ & $73(10)^{a}$ & $77(11)^{\mathrm{ab}}$ & $84(5)^{a b}$ & $91(10)^{b}$ \\
\hline$\dot{\mathrm{V}}_{\mathrm{E}}(1 / \mathrm{min})$ & $22(5)^{a}$ & $36(12)^{\mathrm{b}}$ & $43(8)^{b}$ & $54(10)^{\mathrm{b}}$ \\
\hline$\dot{\mathrm{V}} \mathrm{E} / \mathrm{MVV}(\%)$ & $71(15)^{\mathrm{a}}$ & $90(19)^{\mathrm{ab}}$ & $103(20)^{\mathrm{b}}$ & $110(43)^{\mathrm{b}}$ \\
\hline \multicolumn{5}{|l|}{ Borg score } \\
\hline Dyspnoea & $6.3(2.1)$ & $7.7(2.2)$ & $6.7(2.2)$ & $7.7(1.2)$ \\
\hline Leg fatigue & $3.0(3.3)$ & $6.1(2.9)$ & $5.6(2.4)$ & $8.3(1.2)$ \\
\hline $\mathrm{PaO}_{2}(\mathrm{kPa})$ & $7.7(2.1)^{\mathrm{a}}$ & $8.8(2.0)^{\mathrm{ab}}$ & $10.1(1.7)^{\mathrm{b}}$ & $11.0(2.1)^{\mathrm{b}}$ \\
\hline $\mathrm{SaO}_{2}(\%)$ & $86(12)$ & $90(6)$ & $94(3)$ & $94(3)$ \\
\hline $\mathrm{pH}$ & $7.33(0.05)$ & $7.35(0.04)$ & $7.32(0.05)$ & $7.30(0.05)$ \\
\hline $\mathrm{PCO}_{2}(\mathrm{kPa})$ & $7.4(1.2)$ & $6.1(1.1)^{\mathrm{b}}$ & $6.3(0.9)^{b}$ & $5.6(1.1)^{\mathrm{b}}$ \\
\hline Lactate $(\mathrm{mmol} / \mathrm{l})$ & $2.33(1.43)^{\mathrm{a}}$ & $3.57(1.31)^{\mathrm{ab}}$ & $4.79(2.28)^{\mathrm{bc}}$ & $7.27(1.6)^{\mathrm{c}}$ \\
\hline
\end{tabular}

Values are mean (SD). Values followed by different superscript letters are significantly different. $\dot{\mathrm{V}}_{\mathrm{O}_{2}}=$ oxygen output; $\dot{\mathrm{VE}}=$ minute ventilation; $\mathrm{PaO}_{2}, \mathrm{PaCO}_{2}=$ arterial oxygen and carbon dioxide tensions; $\mathrm{MVV}=$ maximal voluntary ventilation.

Table 4 Activity of citrate synthase (CS) and 3-hydroxyacyl CoA dehydrogenase $(\mathrm{HADH})$ in relation to functional status

\begin{tabular}{lllll}
\hline & $\begin{array}{l}\text { Class } D \\
(n=10)\end{array}$ & $\begin{array}{l}\text { Class } C \\
(n=30)\end{array}$ & $\begin{array}{l}\text { Class } B \\
(n=17)\end{array}$ & $\begin{array}{l}\text { Class } A \\
(n=4)\end{array}$ \\
\hline $\mathrm{CS}(\mu \mathrm{mol} / \mathrm{min} / \mathrm{g}$ muscle $)$ & $\begin{array}{l}20.2(2.2)^{\mathrm{a}} \\
\mathrm{HADH}(\mu \mathrm{mol} / \mathrm{min} / \mathrm{g} \text { muscle })\end{array}$ & $\begin{array}{l}22.0(2.7)^{\mathrm{ab}} \\
5.3(2.4)\end{array}$ & $\begin{array}{l}23.3(2.1)^{\mathrm{bc}} \\
2.0(1.6)\end{array}$ & $\begin{array}{l}25.6(1.2)^{\mathrm{c}} \\
5.6(1.0)\end{array}$ \\
\hline
\end{tabular}

Values are mean (SD). Values followed by different superscript letters are significantly different.

Table 5 Results of the stepwise regression analysis for peak oxygen uptake $\left(\dot{V}_{\mathrm{O}_{2}}\right)$ in $\mathrm{ml} / \mathrm{min} / \mathrm{kg}$

\begin{tabular}{llll}
\hline & Partial $r$ & Cumulative $r^{2}$ & $p$ value \\
\hline FRC (\% pred) & -0.49 & 0.24 & 0.0002 \\
CS ( $\mu$ mol/min/g muscle) & 0.33 & 0.35 & 0.006 \\
$\mathrm{O}_{2}$ desaturation (\%) & -0.34 & 0.46 & 0.002 \\
Age (years) & -0.25 & 0.52 & 0.018 \\
IC (\% pred) & 0.25 & 0.59 & 0.012 \\
\hline
\end{tabular}

FRC = functional residual capacity $\mathrm{CS}=$ citrate synthase IC = inspiratory capacity.

Group mean values for the activity of CS and HADH for the four functional classes of patients are shown in table 4 . The activity of CS decreased progressively with the deterioration in the functional status while that of $\mathrm{HADH}$ was not significantly different between the four classes of patients.

Results of the stepwise regression analysis are provided in table 5 . FRC \% pred, the activity of CS, $\mathrm{O}_{2}$ desaturation during exercise, age, and inspiratory capacity $\%$ pred were found to be significant determinants of peak $\dot{\mathrm{VO}}_{2}$. The regression model explained $59 \%$ of the variance in peak $\dot{\mathrm{V}}_{2} \quad(\mathrm{p}<0.0001)$. The other variables included in the analysis did not significantly improve the ability of this model to predict peak $\dot{\mathrm{V}}_{2}$.

\section{Discussion}

The present results confirm that the oxidative capacity of the vastus lateralis muscle is commonly reduced in COPD. Furthermore, the contribution of poor peripheral muscle oxidative capacity to exercise intolerance in COPD is strongly supported by the progressive reduction in the activity of CS that accompanied the deterioration in the functional status and the stepwise regression analysis which indicated that the activity of CS was a significant determinant of peak $\dot{\mathrm{V}}_{2}$, independent of the impairment in lung function.

Compared with our initial report on oxidative capacity of the skeletal muscle in patients with COPD, ${ }^{6}$ a much larger number of patients was included in the present study and the control group was older and less fit. These methodological improvements strengthen the conclusion that a low oxidative capacity of the skeletal muscle is a frequent finding in patients with moderate to severe COPD. However, the decrease in the activity of CS, which is involved in the citric acid cycle, was greater than that of HADH which regulates the $\beta$ oxidation of fatty acids. In addition, there was a larger overlap between normal subjects and patients with COPD for the activity of HADH than for CS. This discoordinate expression in the activity of $\mathrm{CS}$ and $\mathrm{HADH}$ is intriguing since, in most situations, the activity of all mitochondrial enzymes varies in a parallel and proportional fashion. ${ }^{24} \mathrm{~A}$ differential response in the activity of the enzymes of the citric acid cycle and of $\beta$ oxidation has previously been observed after intense interval training in normal subjects. ${ }^{24}$ The significance of this finding in our patients is unclear. Conceivably, the $\beta$ oxidation pathway could be relatively preserved in order to facilitate the metabolism of blood fatty acids which are increased in a proportion of patients with COPD. ${ }^{25}$ This would advantageously decrease $\mathrm{CO}_{2}$ production and ventilatory requirements because the lipid metabolism leads to lower $\mathrm{CO}_{2}$ production than carbohydrate. The presence of a discoordinate expression of mitochondrial enzymes in patients with COPD is also suggested by a study showing a higher activity of cytochrome oxidase, an enzyme of the electron transport chain, in the skeletal muscle of patients with COPD compared with healthy subjects. ${ }^{26}$ This uncoupling between the different mitochondrial enzymes will need to be explored since it may provide some interesting clues as to the mechanisms of the development of skeletal muscle dysfunction in COPD.

Because a large number of patients with a wide range of peak $\dot{\mathrm{VO}}_{2}(6-25 \mathrm{ml} / \mathrm{min} / \mathrm{kg})$ were included in the present study, the determinants of peak exercise capacity in COPD could be evaluated. In the stepwise regression analysis it was found that peak exercise capacity in patients with COPD could be best explained by a combination of several factors including \% predicted FRC, the activity of CS, oxygen desaturation during exercise, age, and the \% predicted IC. The activity of CS was a significant correlate of peak $\mathrm{VO}_{2}$ independent of the impairment in lung function, and its decrease was accompanied by a progressive worsening in the functional status. Although correlation analysis never proves a causal relationship, these findings and other studies ${ }^{68}$ strongly suggest that alteration in the function of peripheral skeletal muscle contributes to exercise intolerance in COPD. Poor skeletal muscle oxidative capacity probably influences exercise capacity through modifications of the muscle metabolism ${ }^{27}$ which increase lactate and $\mathrm{CO}_{2}$ production and ventilatory needs for a given exercise level. ${ }^{12}$ Impaired muscle metabolism is also associated with premature muscle acidosis, a contributory factor to muscle fatigue and early termination of exercise. ${ }^{28}{ }^{29}$ 
Several physiological mechanisms may explain why FRC and IC were significantly correlated with peak $\dot{\mathrm{V}}_{2}$. At a higher FRC the inspiratory muscles, especially the diaphragm, will be mechanically disadvantaged ${ }^{30}$ and part of the tidal breathing probably occurs in the alinear portion of the pressure-volume curve of the respiratory system, thus increasing the mechanical load on the already disadvantaged respiratory muscles. In exercising flow limited patients with COPD, the increase in tidal volume and thus ventilation can only occur at the expense of the inspiratory reserve volume since the end expiratory lung volume does not decrease below FRC during exercise as is the case in normal subjects. ${ }^{31}{ }^{32}$ For this reason, the ability to increase tidal volume and minute ventilation should be more closely related to the IC than to VC. Lastly, both the level of hyperinflation and the reduction in IC are closely related to the development of dyspnoea during exercise. ${ }^{32}$

Consistent with these notions, IC was found to explain approximately $70 \%$ of the variance in peak exercise work rate in 25 patients with obstructive lung disease. ${ }^{33}$ The much higher contribution of IC to peak exercise capacity in that study compared with the present one is probably due to the use of the absolute value of IC rather than \% predicted to predict peak exercise work rate. Since body size is an important determinant of both variables, the relationship between IC in litres and work capacity in watts will be stronger than the relationship between IC \% predicted and peak exercise capacity normalised for body weight.

The regression model explained $59 \%$ of the variance in peak $\dot{\mathrm{V}}_{2}$. The individual tolerance to the discomfort of exercise is likely to be one factor contributing to peak $\dot{\mathrm{V}}_{2}$ that was not explored in the present study. ${ }^{34}$ As others, ${ }^{8}$ we found that symptom scores at peak exercise tended to decrease with the deterioration in functional status from class A to class D. A likely explanation for this is that patients with poor functional status are less tolerant of the uncomfortable sensations of exercise than more fit patients. ${ }^{8}$ The physiological profile at peak exercise of class D patients with a lower heart rate, $\dot{\mathrm{V}} \mathrm{E} / \mathrm{MVV}$ ratio, and lactate level than patients with a better functional status also exemplified the potential impact of symptom tolerance on peak $\dot{\mathrm{VO}}_{2} \cdot{ }^{34}$ It should be pointed out, however, that the steep increase in dyspnoea and the early rises in $\mathrm{PCO}_{2}$ and lactate in class $\mathrm{D}$ patients are indicative of severe physiological abnormalities and that exercise could not have been tolerated much longer even with a greater tolerance to dyspnoea and leg fatigue.

In conclusion, the present study confirms that the oxidative capacity of the vastus lateralis muscle is reduced in patients with COPD and that the activity of CS is correlated with their functional status. The clinical implication of this study is that exercise intolerance in patients with COPD is of multifactorial origins and that the relative contributions of airflow obstruction, hyperinflation, $\mathrm{O}_{2}$ desaturation, and peripheral muscle dysfunction to exercise intolerance should be addressed to optimise the functional status of a given patient with COPD.

The authors thank Pierre-Michel Simard for his technical support, Serge Simard for his statistical assistance, and Dr Yves Lacasse and Dr Frédéric Sériès for helpful suggestions on the manuscript. This study was supported in part by the Fonds de la recherche en santé du Québec, by la fondation JD Bégin, Université Laval, and by Bayer Corp. Dr Maltais is a clinician scientist of the Fonds de la recherche en santé du Québec.

1 Hughes RL, Katz H, Sahgal V, et al. Fiber size and energy metabolites in five separate muscles from patients with
chronic obstructive lung disease. Respiration 1983;44:3218

2 Jakobsson P, Jorfeldt L, Brundin A. Skeletal muscle metabolites and fibre types in patients with advanced chronic
obstructive pulmonary disease (COPD), with and without chronic respiratory failure. Eur Respir f 1990;3:192-6.

3 Whittom F, Jobin J, Simard PM, et al. Histochemical and morphological characteristics of the vastus lateralis muscle in COPD patients. Comparison with normal subjects and effects of exercise training. Med Sci Sports Exerc 1998;30: effects of

4 Hildebrand IL, Sylvén C, Esbjornsson M, et al. Does hypoxaemia induce transformations of fiber types? Acta Physiol aemia induce transform

5 Satta A, Migliori GB, Spanevello A, et al. Fibre types in skeletal muscles of chronic obstructive pulmonary disease patients related to respiratory function and exercise tolerance. Eur Respir F 1997;10:2853-60.

6 Maltais F, Simard AA, Simard C, et al. Oxidative capacity of the skeletal muscle and lactic acid kinetics during exercise in normal subjects and in patients with COPD. Am $\mathcal{F}$ Respir Crit Care Med 1996;153:288-93.

7 Jakobsson P, Jorfeldt L, Henriksson J. Metabolic enzyme activity in the quadriceps femoris muscle in patients with severe chronic obstructive pulmonary disease. Am 7 Respir Crit Care Med 1995;151:374-7.

8 Hamilton AL, Killian KJ, Summers E, et al. Muscle strength, symptom intensity and exercise capacity in patients with cardiorespiratory disorders. Am $\mathcal{F}$ Respir Crit patients with cardiorespiratory
Care Med 1995;152:2021-31.

9 Maltais F, Sullivan MJ, Leblanc P, et al. Altered expression of myosin heavy chain in the vastus lateralis muscle in of myosin heavy chain in the vastus lateralis m
patients with COPD. Eur Respir $\mathcal{F}$ 1999;13:850-4.

10 Richardson RS, Sheldon J, Poole DC, et al. Evidence of skeletal muscle metabolic reserve during whole body exercise in patients with chronic obstructive pulmonary disease. Am F Respir Crit Care Med 1999;159:881-5.

11 Holloszy JO, Coyle EF. Adaptations of skeletal muscle to endurance exercise and their metabolic consequences. $\mathcal{F}$ Appl Physiol 1984;56:831-8.

12 Casaburi R, Patessio A, Ioli F, et al. Reductions in exercise lactic acidosis and ventilation as a result of exercise training in patients with obstructive lung disease. Am Rev Respir Dis 1991;143:9-18.

13 Maltais F, Leblanc P, Simard C, et al. Skeletal muscle adaptation to endurance training in patients with chronic obstructive pulmonary disease. Am $\mathcal{F}$ Respir Crit Care Med 1996;154:442-7.

14 Saltin B, Henriksson J, Nygaard E, et al. Fiber types and metabolic potentials of skeletal muscles in sedentary man and endurance runners. Ann NY Acad Sci 1977;301:3-29.

15 Knudson RI, Slatin RC, Lebowitz MD, et al. The maximal Knudson RJ, Slatin RC, Lebowitz MD, et al. The maximal
expiratory flow-volume curve. Normal standards, variability and effects of age. Am Rev Respir Dis 1976;113:587600 .

16 Goldman HI, Becklake MR. Respiratory function tests: normal values at median altitudes and the prediction of normal results. Am Rev Tuberc 1959;79:454-67.

17 Cotes JE, Hall AM. The transfer factors for the lung; normal values in adults. In: Arcangeli P, ed. Normal values for respiratory function in man. Torino: Panminerva Medica, 1970: 327-43.

18 American Thoracic Society. Standards for the diagnosis and care of patients with chronic obstructive pulmonary disease (COPD) and asthma. Am Rev Respir Dis 1987;136:225-44.

19 Bergström J. Muscle electrolytes in man. Determination by neutron activation analysis on needle biopsy specimens. A study on normal subjects, kidney patients and patients with chronic diarrhoea. Scand f Clin Lab Invest 1962;14:1-110. Chronic diarrhoea. Scand F Clin Lab Invest 1962;14:1-110. hexokinase, phosphorylase, phosphofructokinase, glycerol phosphate dehydrogenase, lactate desydrogenase, octopine dehydrogenase, phosphoenolpyruvate carboxykinase, nucleoside diphosphatekinase, glutamate-oxalate transaminase and arginine kinase in relation of carbohydrate utilisation in muscle from invertebrates. Biochem $\mathcal{F} 1976 ; 160$ : 447-62.

21 Srere PA. Citrate synthase. Methods Enzymol 1969;13:3-11.

22 Weber KT, Janicki JS. Lactate production during maximal and submaximal exercise in patients with chronic heart failure. $\mathcal{F}$ Am Coll Cardiol 1985;6:717-24.

23 Clark TJH, Freedman S, Campbell EJM, et al. The ventilatory capacity of patients with chronic airway obstruction.
Clin Sci 1969;36:307-16.

24 Saltin B, Gollnick PD. Skeletal muscle adaptability: significance for metabolism and performance. In: Peachey LD, cance for metabolism and performance. In: Peachey LD, Bethesda, MD: American Physiological Society, 1982: 555-631. 
25 Jakobsson P, Jorfeldt L, von Schenck H. Fat metabolism and its response to infusion of insulin and glucose in patients with advanced chronic obstructive pulmonary disease. Clin Physiol 1995;15:319-29.

26 Sauleda J, García-Palmer F, Wiesner RJ, et al. Cytochrome oxidase activity and mitochondrial gene expression in skeletal muscle of patients with chronic obstructive pulmonary disease. Am $\mathcal{F}$ Respir Crit Care Med 1998;157:1413-7.

27 Kutsuzawa T, Shioya S, Kurita D, et al. ${ }^{31} \mathrm{P}-\mathrm{NMR}$ study of skeletal muscle metabolism in patients with chronic respiratory impairment. Am Rev Respir Dis 1992;146:1019-24.

28 Westerblad H, Lee JA, Lannergren J, et al. Cellular mechanisms of fatigue in skeletal muscle. Am $\mathcal{F}$ Physiol 1991;261: C195-209

29 Maltais F, Jobin J, Sullivan MJ, et al. Metabolic and hemodynamic responses of the lower limb during exercise in patients with COPD. $f$ Appl Physiol 1998;84:1573-80.
30 Similowski T, Yan S, Gauthier AP, et al. Contractile properties of the human diaphragm during chronic hyperinflation. N Engl f Med 1991;325:917-23.

31 Dodd DS, Brancatisano T, Engel LA. Chest wall mechanics during exercise in patients with severe chronic air-flow obstruction. Am Rev Respir Dis 1984;129:33-8.

32 O'Donnell DE, Webb KA. Exertional breathlessness in patients with chronic airflow limitation. Am Rev Respir Dis 1993;148:1351-7.

33 Murariu C, Ghezzo H, Milic-Emili J, et al. Exercise limitation in obstructive lung disease. Chest 1998;114:9658.

34 Killian KJ, Leblanc P, Martin DH, et al. Exercise capacity and ventilatory, circulatory, and symptom limitation in patients with airflow limitation. Am Rev Respir Dis 1992;146:935-40. 